\title{
A Method of Age Estimation of Radioactive Fallout by Measuring the Activity of ${ }^{95} \mathrm{Nb}$
}

\author{
Tadashi TATEWAKI \\ Institute of Physics, Faculty of Engineering, \\ Shinshu University \\ Wakasato, Nagano-shi, Japan \\ Received January 11, 1973
}

\begin{abstract}
In this paper a new method is described for estimating the age of a given radio active fallout by a $\mathrm{Ge}(\mathrm{Li}) \gamma$-ray detector with high resolution. The age is calculated by this method from the two measured values of the activity of ${ }^{95} \mathrm{Nb}$ at a given time on December 24, 1967. of the ages, and expected errors for the results and ones by the activity ratios of ${ }^{95} \mathrm{Zr}$ to ${ }^{95} \mathrm{Nb}$. The number of the atoms of ${ }^{95} \mathrm{Nb}$ and the necessary measurement accuracies for the errors 1 to 2 days, are given in the tables.
\end{abstract}

\section{Introduction}

To estimate the age of a radioactive fallout, several methods ${ }^{1) \sim 8}$ have been proposed so far. The present author, in this connection, have paid attention to the $\gamma$ activity ratio of ${ }^{95} \mathrm{Zr}$ to ${ }^{95} \mathrm{Nb}$ belonging to the same decay chain of mass number 95 , and the ages of radioactive fallout were estimated from its ratios ${ }^{9)}$. In the present study, another method has been developed, which utilized twice the measurement of $\gamma$ activity of ${ }^{95} \mathrm{Nb}$ at a certain time interval. The method was applied to the hot particles (highly radioactive fallout particles) due to the 7th Chinese nuclear test explosion carried out on December 24, 1967. The results of the estimated ages were in fairly good agreement with the actual ones. The expected errors for the results and the necessary measurement accuracies for the number of the atoms of ${ }^{95} \mathrm{Nb}$ and the time intervals to estimate the age of a radioactive fallout within the errors 1 to 2 days, are discussed.

\section{Principle of Age Estimation Method}

In the decay chain of mass-9510), the halflives of ${ }^{95} \mathrm{Kr},{ }^{95} \mathrm{Rb},{ }^{95} \mathrm{Sr}$ and ${ }^{95} \mathrm{Y}$, the precursors of ${ }^{95} \mathrm{Zr}$, are by far shorter than that of ${ }^{95} \mathrm{Zr}$. It can therefore be considered for the present purpose that the time of a nuclear explosion is the time when ${ }^{95} \mathrm{Zr}$ is produced and starts to decay simultaneously. According to L.E. Weaver, et al.'s data ${ }^{11}$, the independent yield values of ${ }^{95} \mathrm{Nb}$ and ${ }^{95 m} \mathrm{Nb}$ are so small as compared with the cumulative yield values of ${ }^{95} \mathrm{Zr}$, that the former values can be neglected. The number of the atoms of ${ }^{95} \mathrm{Zr}$ and ${ }^{95} \mathrm{Nb}$ at a time $t$ in relation to the time of the nuclear explosion $(t=0), N_{1}$ and $N_{3}$, respectively, are expressed by the following equations

$$
\begin{aligned}
& N_{1}=N_{1,0} e^{-\lambda_{1} t}, \\
& N_{3}=\lambda_{1} N_{1,0}\left(A e^{-\lambda_{1} t}+B e^{-\lambda_{2} t}-C e^{-\lambda_{3} t}\right),
\end{aligned}
$$
where

$$
\left.\begin{array}{l}
A=\frac{1}{\lambda_{3}-\lambda_{1}}\left(a_{1}+\frac{a_{2} \lambda_{2}}{\lambda_{2}-\lambda_{1}}\right) \\
B=\frac{a_{2} \lambda_{2}}{\left(\lambda_{2}-\lambda_{1}\right)\left(\lambda_{2}-\lambda_{3}\right)} \\
C=\frac{1}{\lambda_{3}-\lambda_{1}}\left(a_{1}+\frac{a_{2} \lambda_{2}}{\lambda_{2}-\lambda_{3}}\right)
\end{array}\right\} .
$$

Here, $N_{1,0}$ is the number of the atoms of ${ }^{95} \mathrm{Zr}$ at $t=0 ; \lambda_{1}, \lambda_{2}$ and $\lambda_{3}$ are the decay con- 
stants of ${ }^{95} \mathrm{Zr},{ }^{95 m} \mathrm{Nb}$ and ${ }^{95} \mathrm{Nb}$, respectively; and the branching ratios for ${ }^{95} \mathrm{Zr} \rightarrow{ }^{95} \mathrm{Nb}$ and ${ }^{95} \mathrm{Zr} \rightarrow{ }^{95 m} \mathrm{Nb}$ are $a_{1}$ and $a_{2}$ respectively. Upon substitution of the decay constants values and the branching ratios $a_{1}=0.98$ and $a_{2}=$ 0.02 into Eq.( 3 ), the following are derived: $A=110.9, B=0.1284$ and $C=111.1$.

With the number of the atoms of ${ }^{95} \mathrm{Nb}$ at time $t_{1}$ and $t_{2}$ after the nuclear explosion represented by $N_{3,1}$ and $N_{3,2}$, from Eq.(2), the following equation is obtained

$$
\frac{N_{3,1}}{N_{3,2}}=\frac{A e^{-\lambda_{1} t_{1}}+B e^{-\lambda_{2} t_{1}}-C e^{-\lambda_{3} t_{1}}}{A e^{-\lambda_{1} t_{3}}+B e^{-\lambda_{2} t_{2}}-C e^{-\lambda_{3} t_{2}}} .
$$

It is transformed to

$$
\begin{aligned}
& A e^{-\lambda_{1} t_{1}}\left\{\frac{N_{3,1}}{N_{3,2} \mid} e^{-\lambda_{1}\left(t_{2}-t_{1}\right)}-1\right\} \\
& +B e^{-\lambda_{3} t_{1}}\left\{\frac{N_{3,1}}{N_{3,2}} e^{-\lambda_{2}\left(t_{3}-t_{1}\right)}-1\right\} \\
& \quad-C e^{-\lambda_{3} t_{1}}\left\{\frac{N_{3,1}}{N_{3,2}} e^{-\lambda_{3}\left(t_{2}-t_{1}\right)}-1\right\}=0 .
\end{aligned}
$$

With the expressions

$$
\left.\begin{array}{rl}
\tau=t_{2}-t_{1}, \quad k_{11} & =\frac{N_{3,1}}{N_{3,2}} e^{-\lambda_{1} \tau}-1 \\
k_{12}=\frac{N_{3,1}}{N_{3,2}} e^{-\lambda_{2} \tau}-1, k_{13} & =\frac{N_{3,1}}{N_{3,2}} e^{-\lambda_{3} \tau}-1
\end{array}\right\},(5)
$$

the equation (4) takes the following form:

$$
\begin{aligned}
f\left(t_{1}\right)= & A k_{11} e^{-\lambda_{1} t_{1}}+B k_{12} e^{-\lambda_{2} t_{1}} \\
& -C k_{13} e^{-\lambda_{3} t_{1}}=0 .
\end{aligned}
$$

If, now, the time interval $\tau$ between the two measuring times $t_{1}$ and $t_{2}$ and the corresponding number of the atoms of ${ }^{95} \mathrm{Nb}$, $N_{3,1}$ and $N_{3,2}$, are measured, the values of $k_{11}, k_{12}$ and $k_{13}$ can be obtained from Eq. (5); so that the age of radioactive fallout, $t_{1}$, is derived from Eq.(4a). As $\lambda_{2}>\lambda_{1}$ and $\lambda_{2}>\lambda_{3}$, the second term in Eq. (4a) may be neglected. The age of radioactive fallout, $t_{1}$ can be easily obtained from Eq. (6).

$$
A k_{11} e^{-\lambda_{1} t_{1}}-C k_{13} e^{-\lambda_{3} t_{1}}=0 .
$$

As $A=110.9$ and $C=111.1, t_{1}$ becomes:

$$
t_{1}=\frac{1}{\lambda_{3}-\lambda_{1}} \ln \left[\frac{k_{13}}{k_{11}}\right]=\frac{1}{\lambda_{3}-\lambda_{1}} \ln \left[\frac{\frac{N_{3,1}}{N_{3,2}} e^{-\lambda_{3} \tau}-1}{\frac{N_{3,1}}{N_{3,2}} e^{-\lambda_{1} \tau}-1}\right] \text {. }
$$

If the errors of measurement for $N_{3,1}$, $N_{3,2}$ and $\tau$ are represented by $\Delta N_{3,1}, \Delta N_{3,2}$ and $\Delta \tau$ respectively, the error $\Delta t_{1}$, in the estimation for $t_{1}$, can be derived with the law of propargation of the errors as follows,

$$
\begin{aligned}
\left(\Delta t_{1}\right)^{2}= & \left(\frac{\partial t_{1}}{\partial N_{3,1}}\right)^{2}\left(\Delta N_{3,1}\right)^{2} \\
& +\left(\frac{\partial t_{1}}{\partial N_{3,2}}\right)^{2}\left(\Delta N_{3,2}\right)^{2}+\left(\frac{\partial t_{1}}{\partial \tau}\right)^{2}(\Delta \tau)^{2} .
\end{aligned}
$$

Therefore

$$
\begin{aligned}
\Delta t_{1}= & \frac{1}{k_{11} \cdot k_{13}\left(\lambda_{3}-\lambda_{1}\right)}\left[\left(e^{-\lambda_{1} \tau}-e^{-\lambda_{3} \tau}\right)^{2} \cdot\right. \\
\{( & \left.\left.N_{3,2} \cdot \Delta N_{3,1}\right)^{2}+\left(N_{3,1} \cdot \Delta N_{3,2}\right)^{2}\right\} \\
& +\left\{N_{3,2}\left(\lambda_{3} e^{-\lambda_{3} \tau}-\lambda_{1} e^{-\lambda_{1} \tau}\right)\right. \\
& \left.\left.+N_{3,1}\left(\lambda_{1}-\lambda_{3}\right) e^{-\left(\lambda_{1}+\lambda_{3}\right) \tau}\right\}^{2}(\Delta \tau)^{2}\right]^{1 / 2}
\end{aligned}
$$

If, then $\Delta \tau=0$, the error of $t_{1}, \Delta t_{10}$ becomes

$$
\begin{aligned}
\Delta t_{10} & =\frac{e^{-\lambda_{1} \tau}-e^{-\lambda_{3} \tau}}{k_{11} \cdot k_{13}\left(\lambda_{3}-\lambda_{1}\right)} \cdot \\
& \sqrt{\left(N_{3,2} \cdot \Delta N_{3,1}\right)^{2}} \overline{+\left(N_{3,1} \cdot \Delta N_{3,2}\right)^{2}} .
\end{aligned}
$$

\section{Experimental}

\subsection{Sample}

Radioactive fallout samples due to the 7 th Chinese nuclear test explosion on December 24, 1967 were collected in Nagano City over the period of December 26 to 28, 1967. Of these samples, No. 1 contained a single hot particle and No. 2 seven hot ones.

\subsection{Apparatus}

In the measuring apparatus used, the coaxial type, $\mathrm{Ge}(\mathrm{Li}) \boldsymbol{\gamma}$-ray detector of effective volume $22 \mathrm{cc}$ and the $\gamma$-ray spectrometer are ORTEC's manufacture; and the 800 channel pulse height analyzer is Toshiba's.

\section{Experimental Results and Estimation}

Gamma-ray spectra measured for the radioactive fallout samples are shown in Fig. 1. The photopeak of ${ }^{95} \mathrm{Zr}(724 \mathrm{keV}) \gamma^{-}$ rays is well resolved, and those of ${ }^{95} \mathrm{Zr}(757$ $\mathrm{keV}$ ) and ${ }^{95} \mathrm{Nb}(766 \mathrm{keV}) \gamma$-rays take the form of a partly resolved complex photopeak. The latter photopeak can be resolved into the two respective components by means of a two component photopeak separation procedure ${ }^{(2)}$. The photopeak area of ${ }^{95} \mathrm{Nb}$ (766 keV) $\gamma$-rays thus obtained is devided by the counting time; the result given in the 


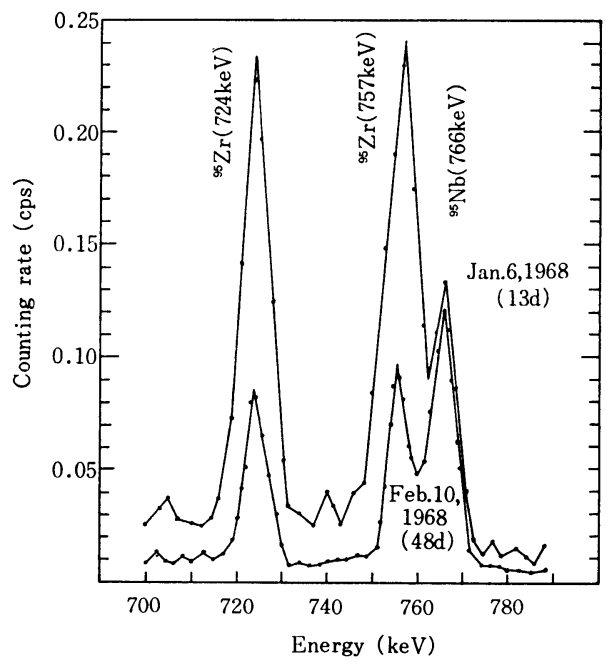

Fig. 1 (above) $\gamma$-ray spectrum of sum s.: $^{-1}$ No. 1 contained a single hot particle measured on Jan. 6, 1968, 13 days after the 7th Chinese nuclear test explosion.

(below) $\gamma$-ray spectrum of the same sample measured on Feb. 10, 1968, 48 days after that. count per sec is proportional to the intensity of ${ }^{95} \mathrm{Nb}(766 \mathrm{keV}) \gamma$-rays. For the period of January 6 to February 29, 1968, the $r$-ray spectra for sample No. 1 and No. 2 were measured. The values of the counting rate of ${ }^{95} \mathrm{Nb}(766 \mathrm{keV}) \gamma$-rays are shown in Table 1. After choosing the combinations of $t_{1}$ and $t_{2}$ for both samples No. 1 and No. 2 in this table, the ages $t_{1}$ of the hot particles, were then calculated with Eq. (4a) and (7) respectively, and also the deviations from the true value and the corresponding percentage deviations. These results are given in Table 2.

The value of $t_{1}$ is derived with Eq.(4a), as follows. With $t_{1}$ as the variable, the values of $f\left(t_{1}\right)$ are first calculated. The value of $t_{1}$ corresponding to the value of $f\left(t_{1}\right)$ turning from positive to negative, i.e. the value where the curve of $f\left(t_{1}\right)$ intersects the abscissa, is the value of the age desired. This procedure is illustrated in Fig. 2. If $\tau$ is over 15 days, the values of $t_{1}$ estimated from Eq. (4a) and (7), are almost the same.

Table 1 Counting rate of ${ }^{95} \mathrm{Nb}(766 \mathrm{keV}) \gamma$-rays

\begin{tabular}{c|c|c|c|c|c|c}
\hline Sample & \multicolumn{3}{|c|}{ No. 1 } & \multicolumn{2}{c}{ No. 2 } \\
\cline { 2 - 6 } Measuring date & $6 / 1 / 68$ & $26 / 1 / 68$ & $10 / 2 / 68$ & $29 / 2 / 68$ & $26 / 1 / 68$ & $19 / 2 / 68$ \\
\hline $\begin{array}{c}\text { Counting rate of } \\
{ }^{95} \begin{array}{c}\mathrm{Nb}(766 \mathrm{keV}) \\
{[\mathrm{cps}]}\end{array}\end{array}$ & 0.3726 & 0.6741 & 0.7650 & 0.7918 & 5.9053 & 7.3890 \\
\hline
\end{tabular}

Table 2 Estimated ages and those errors of the hot particles due to the 7th Chinese nuclear test explosion on Dec. 24, 1967

\begin{tabular}{|c|c|c|c|c|c|c|c|c|c|c|}
\hline \multirow{2}{*}{ Sample } & \multirow{2}{*}{ Case } & \multicolumn{2}{|c|}{ Measuring date } & \multirow{2}{*}{$\mid \begin{array}{c}\text { Time } \\
\text { interval } \\
\tau[\mathrm{d}] \\
\left(=t_{2}^{\prime}-t_{1}^{\prime}\right)\end{array}$} & \multirow{2}{*}{$\begin{array}{l}\text { Ratio of } \\
\text { number of } \\
\text { the atoms of } \\
{ }^{95} \mathrm{Nb}, N_{3,1} / N_{3,2}\end{array}$} & \multirow{2}{*}{$\begin{array}{l}\text { True } \\
\text { value } \\
\text { of age }\end{array}$} & \multicolumn{2}{|c|}{$\begin{array}{l}\text { Estimated age } \\
t_{1}[\mathrm{~d}]\end{array}$} & \multicolumn{2}{|c|}{$\begin{array}{l}\text { Deviation of } t_{1} \text { value } \\
\text { estimated from Eq. (7) }\end{array}$} \\
\hline & & $t_{1}^{\prime}$ & $t_{2}^{\prime}$ & & & & $\begin{array}{l}\text { Value } \\
\text { from } \\
\text { Eq.(4a) }\end{array}$ & $\begin{array}{l}\text { Value } \\
\text { from } \\
\text { Eq. (7) }\end{array}$ & $\begin{array}{l}\text { Deviation } \\
{[d]}\end{array}$ & $\begin{array}{c}\text { Percentage } \\
\text { deviation } \\
{[\%]}\end{array}$ \\
\hline \multirow{6}{*}{ No. 1} & (1) & $6 / 1 / 68$ & $26 / 1 / 68$ & 20 & $0.3726 / 0.6741$ & \multirow{3}{*}{13.00} & 14.07 & 14.08 & +1.08 & +7.7 \\
\hline & (2) & $6 / 1 / 68$ & $10 / 2 / 68$ & 35 & $0.3726 / 0.7650$ & & 14.41 & 14.42 & +1.42 & +9.8 \\
\hline & (3) & $6 / 1 / 68$ & $29 / 2 / 68$ & 54 & $0.3726 / 0.7918$ & & 14.64 & 14.64 & +1.64 & +11.2 \\
\hline & (4) & $26 / 1 / 68$ & $10 / 2 / 68$ & 15 & $0.6741 / 0.7650$ & \multirow{2}{*}{33.00} & 36.12 & 36.11 & +3.11 & +8.6 \\
\hline & (5) & $26 / 1 / 68$ & $29 / 2 / 68$ & 34 & $0.6741 / 0.7918$ & & 36.35 & 36.35 & +3.35 & +9.2 \\
\hline & (6) & $10 / 2 / 68$ & $29 / 2 / 68$ & 19 & $0.7650 / 0.7918$ & 48.00 & 51.71 & 51.71 & +3.71 & +7.1 \\
\hline No. 2 & (7) & $26 / 1 / 68$ & $19 / 2 / 68$ & 24 & $5.9053 / 7.3890$ & 33.00 & 30.72 & 30.71 & -2.29 & -7.4 \\
\hline
\end{tabular}




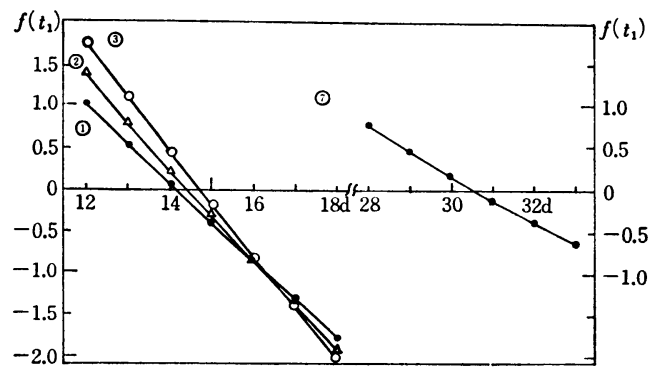

Fig. 2 Curves of the function $f\left(t_{1}\right)$ represented by Eq. (4a) for sample No. 1 and No. 2.

In order to estimate the value of $t_{1}$, therefore, the use of rather simple equation (7) may be sufficient.
In Table 2, the estimated values of the time elapsed after the nuclear explosion, $t_{1}$, on January 6, 1968 obtained with Eq. (7) for the cases (1), (2) and (3) are 14.08, 14.42 and 14.64 days, respectively, being in agreement with the true values within the errors 1 2 days. The corresponding errors are about 2.5 days in the case (7) and 3 4 days in the cases (4), (5) and (6). These errors involved in the age estimation are thus in the range of about $7 \sim 11 \%$.

\section{Errors in Estimation}

If the date of the nuclear explosion i.e. the true value of the elapsed time after that,

Table 3 Expected errors in age estimation of radioactive fallout

\begin{tabular}{|c|c|c|c|c|c|c|c|}
\hline \multirow{2}{*}{$\begin{array}{c}\text { Time } \\
\text { interval } \\
\tau[\mathrm{d}]\end{array}$} & \multirow{2}{*}{$\underset{[\%]}{\text { Measurement }} \underset{\substack{\text { accuracies* } \\
[\%]}}{ }$} & \multicolumn{2}{|c|}{$t_{1}=15.0[\mathrm{~d}]$} & \multicolumn{2}{|c|}{$t_{1}=30.0[\mathrm{~d}]$} & \multicolumn{2}{|c|}{$t_{1}=50.0[\mathrm{~d}]$} \\
\hline & & $\Delta t_{1}$ & $\Delta t_{10}$ & $\Delta t_{1}$ & $\Delta t_{10}$ & $\Delta t_{1}$ & $\Delta t_{10}$ \\
\hline \multirow{4}{*}{1.0} & 0.1 & 0.35 & 0.34 & 1.32 & 1.32 & 3.66 & 3.66 \\
\hline & 0.2 & 0.70 & 0.67 & 2.64 & 2.63 & 7.32 & 7.32 \\
\hline & 0.5 & 1.74 & 1.68 & 6.59 & 6.58 & 18.30 & 18.29 \\
\hline & 1.0 & 3.48 & 3.36 & 13.18 & 13.16 & 36.59 & 35.59 \\
\hline \multirow{4}{*}{2.0} & 0.1 & 0.20 & 0.18 & 0.68 & 0.68 & 1.86 & 1.86 \\
\hline & 0.2 & 0.40 & 0.36 & 1.36 & 1.36 & 3.73 & 3.72 \\
\hline & 0.5 & 1.00 & 0.89 & 3.41 & 3. 39 & 9.31 & 9.31 \\
\hline & 1.0 & 1.99 & 1.79 & 6.82 & 6.78 & 18.54 & 18.53 \\
\hline \multirow{4}{*}{5.0} & 0.1 & 0.12 & 0.08 & 0.31 & 0.30 & 0.79 & 0.79 \\
\hline & 0.2 & 0.24 & 0.17 & 0.61 & 0.59 & 1.58 & 1.58 \\
\hline & 0.5 & 0.59 & 0.42 & 1.52 & 1.48 & 3.95 & 3.94 \\
\hline & 1.0 & 1.18 & 0.84 & 3.05 & 2.97 & 7.90 & 7.89 \\
\hline \multirow{4}{*}{10.0} & 0.2 & 0.18 & 0.11 & 0.36 & 0.34 & 0.86 & 0.86 \\
\hline & 0.5 & 0.45 & 0.26 & 0.90 & 0.85 & 2.16 & 2.16 \\
\hline & 1.0 & 0.91 & 0.53 & 1.80 & 1.70 & 4.32 & 4.31 \\
\hline & 2.0 & 1.82 & 1.05 & 3.61 & 3.40 & 8.63 & 8.62 \\
\hline \multirow{4}{*}{30.0} & 0.2 & 0.10 & 0.06 & 0.17 & 0.16 & 0.39 & 0.39 \\
\hline & 0.5 & 0.25 & 0.16 & 0.44 & 0.43 & 0.98 & 0.96 \\
\hline & 1.0 & 0.51 & 0.32 & 0.87 & 0.85 & 1.96 & 1.93 \\
\hline & 2.0 & 1.01 & 0.63 & 1.74 & 1.71 & 3.92 & 3.86 \\
\hline \multirow{4}{*}{50.0} & 0.2 & 0.06 & 0.05 & 0.15 & 0.14 & 0.34 & 0.29 \\
\hline & 0.5 & 0.14 & 0.14 & 0.36 & 0.34 & 0.86 & 0.73 \\
\hline & 1.0 & 0.28 & 0.27 & 0.73 & 0.69 & 1.72 & 1.46 \\
\hline & 2.0 & 0.56 & 0.55 & 1.46 & 1.37 & 3.44 & 2.91 \\
\hline
\end{tabular}

* Measurement accuracies [\%]: $\left(\Delta N_{3,1} / N_{3,1}\right) \times 100 \%=\left(\Delta N_{3,2} / N_{3,2}\right) \times 100 \%=(\Delta \tau / \tau) \times 100 \%$ $=0.1,0.2,0.5,1.0$ and $2.0[\%]$, respectively. 
is available, it is a simple matter to calculate the deviation of the estimated value of the age for radioactive fallout from the true one. In this connection, the errors in the estimated age $t_{1}$ of radioactive fallout, i.e. the values of $\Delta t_{1}$ and $\Delta t_{10}$ are calculated with Eq. (8) and (9), respectively, for the conditions listed below. The values of estimated $t_{1}$ and these expected errors $\Delta t_{1}, \Delta t_{10}$ derived are given in Table 3.

The conditions are:

(i) $t_{1}=15.0,30.0$ and 50.0 days.

(ii) $\tau=1.0,2.0,5.0,10.0,30.0$ and 50.0 days.

(iii) The measurement accuracies of $N_{3,1}$, $N_{3,2}$ and $\tau$ expressed in percentage errors, $\left(\Delta N_{3,1} / N_{3,1}\right) \times 100(\%),\left(\Delta N_{3,2} N_{3,2}\right)$ $\times 100(\%)$ and $(\Delta \tau / \tau) \times 100(\%)$, respectively.

Each value $=0.1,0.2,0.5,1.0$ and $2.0(\%)$. The number of the atoms of ${ }^{95} \mathrm{Nb}$ at the times $t_{1}^{\prime}$ and $t_{2}^{\prime}$, i.e. the values of $N_{3,1}$ and $N_{3,2}$ are the theoretical ones calculated from Eq.(2).

As seen Table 3, for the given accuracies in the respective measurements, the error in age estimation, $\Delta t_{1}$ or $\Delta t_{10}$, increases with the increase of the value of $t_{1}$; and with the increase of the time interval $\tau$, the error $\Delta t_{1}$ or $\Delta t_{10}$ decreases. Therefore, it is seen that when the time interval $\tau$ is small, i.e. the time $t_{2}$ is closed to $t_{1}$, the error $\Delta t_{1}$ or $\Delta t_{10}$ cannot be small, unless the measurement accuracies, $\left(\Delta N_{3,1} / N_{3,1}\right) \times 100(\%),\left(\Delta N_{3,2} / N_{3,2}\right)$ $\times 100(\%)$ and $(\Delta \tau / \tau) \times 100(\%)$, are fairly low. The measuring apparatus must thus have good and stable performance to increase these measurement accuracies, and furthermore, high reproducibility. In Table 3 , the values of $\Delta t_{1}$ and $\Delta t_{10}$ are nearly the same. The measurement accuracies required for $N_{3,1}, N_{3,2}$ and $\tau$ in estimating the ages of the radioactive fallout within the errors of one or two days are indicated in Table 4. To estimate the value of $t_{1}$ with the error $\Delta t_{1} \leqq 1.0$ day and with the time interval of measurement as small as possible, the necessary measurement accuracies are smaller than $0.2 \%$ for $t_{1}=15.0$ days with $\tau=1.0$ day. For $t_{1}=30.0$ days, they are lower than $0.1 \%$ with $\tau=2.0$ days; and for $t_{1}=\mathbf{5 0 . 0}$ days, less than $0.1 \%$ with $\tau=5.0$ days.

Table 4 The necessary measurement accuracies for the numbers of the atoms of ${ }^{95} \mathrm{Nb}, N_{3,1}, N_{3,2}$ and time interval $\tau$ to estimate the age $t_{1}$ of radioactive fallout within the errors 1 to 2 days

\begin{tabular}{|c|c|c|c|c|c|c|}
\hline \multirow{3}{*}{$\begin{array}{c}\text { Time } \\
\text { interval } \\
\tau[\mathrm{d}]\end{array}$} & \multicolumn{6}{|c|}{$\begin{aligned} \text { Measurement accuracies* } & \left(\left(\Delta N_{3,1} / N_{3,1}\right) \times 100,\left(\Delta N_{3,2} / N_{3,2}\right) \times 100,\right. \\
& (\Delta \tau / \tau) \times 100[\%])\end{aligned}$} \\
\hline & \multicolumn{2}{|c|}{$t_{1}=15.0[\mathrm{~d}]$} & \multicolumn{2}{|c|}{$t_{1}=30.0[\mathrm{~d}]$} & \multicolumn{2}{|c|}{$t_{1}=50.0[\mathrm{~d}]$} \\
\hline & $\Delta t_{1} \leqq 1.0$ & $\Delta t_{1} \leqq 2.0$ & $\Delta t_{1} \leqq 1.0$ & $\Delta t_{1} \leqq 2.0$ & $\Delta t_{1} \leqq 1.0$ & $\Delta t_{1} \leqq 2.0$ \\
\hline 1.0 & 0.2 & 0.5 & $<0.1$ & 0.1 & $<0.1$ & $<0.1$ \\
\hline 2.0 & 0.5 & 1.0 & 0.1 & 0.2 & $<0.1$ & 0.1 \\
\hline 5.0 & 0.5 & 1.0 & 0.2 & 0.5 & 0.1 & 0.2 \\
\hline 10.0 & 1.0 & 2.0 & 0.5 & 1.0 & 0.2 & 0.2 \\
\hline 30.0 & 2.0 & 2.0 & 1.0 & 2.0 & 0.5 & 1.0 \\
\hline 50.0 & 2.0 & 5.0 & 1.0 & 2.0 & 0.5 & 1.0 \\
\hline
\end{tabular}

\section{Discussion}

It is difficult, however, to estimate accurately the age $t_{1}$ of radioactive fallout by the present method at an early stage of the lapse of time after the nuclear explosion for example, within 15 days after it. This is because, similarly in the case of estimat- 
ing the age by the activity ratio of ${ }^{95} \mathrm{Zr}$ to ${ }^{95} \mathrm{Nb}$, the photopeak due to ${ }^{95} \mathrm{Nb}(766 \mathrm{keV}) \gamma$ rays has not grown sufficiently yet during this interval and has also a possibility of disturbance by the photopeak of ${ }^{132} \mathrm{I}(773 \mathrm{keV})$ $\gamma$-rays. As seen in Fig. 1, in the sample No. 1 with very little amount of ${ }^{132} I$ due to the fractionation effect, which has volatile behaviour, the fallout age 13.0 days (smaller than 15.0 days) was estimated as $14.08 \sim 14.64$ days with the errors of $1.0 \sim 2.0$ days. The present method may not be applicable to the case when the samples are " mixed radioactive fallout" due to the close succession of nuclear explosions. In any case, reasonable attention must be given to the application of this method to avoid gross errors. As compared with the previous method of utilizing the activity ratio of ${ }^{95} \mathrm{Zr}$ to ${ }^{95} \mathrm{Nb}$, in this method it is necessary to make, at least, one additional measurement of the $r$-ray spectrum at a certain time interval. The estimated values of radioactive fallout age by the both methods are in fairly good agreement.

\section{Conclusion}

A new method for the age estimation of a given radioactive fallout has been developed. The method was applied to the hot particles due to the 7 th Chinese nuclear test explosion carried out on December 24, 1967. The ages of the hot particles thus estimated were in fairly good agreement with the actual values, and further with those estimated by the activity ratios of ${ }^{95} \mathrm{Zr}$ to ${ }^{95} \mathrm{Nb}$.

\section{Acknowledgment}

The author is deeply indebted to Dr. Isao Fujii and Mr. Koichi Onodera of the Research and Development Center, Tokyo Shibaura Electric Co. Ltd., for their aid in the present measurements.

\section{References}

1) K. Way, E.P. Wigner: Phys. Rev., 73, 11 (1949)

2) H.F. Hunter, N.E. Ballou: Nucleonics, 9, (5) C-2 (1951)

3) F. Yamasaki, H. Kaneko: J. Sci. Res. Inst., 49, 137 43 (1955)

4) Y. Nishiwaki, et al.: Ann. Rept. Kinki Univ. Atomic Energy Res. Institute, 1, 88 90 (1963)

5) T. Sotobayashi, et al.: Nature, 215, 728 (1967)

6) T. Sotobayashi, et al.: Bull. Chem. Soc. Jap., 41, (11) 2796 (1968)

7) T. Mamuro, Y. Matsuda: J. Rad. Res., 10-3-4, 126 32 (1969)

8) I. Fujii, K. Onodera: J. Inorg. Nucl. Chem., 31, (7) 1907 (1969)

9) T. Tatewaki: Radioisotopes, 21, (4) 230 $\sim 34$ (1972)

10) S. Katcoff: Nucleonics, 18, 201 (1960)

11) L.E. Weaver, et al.: USNRL-TR-633, 21

12) C.L. Carnahan: Nucl. Instr. Methods, 30, 165 (1964)

\title{
要 旨
}

\section{${ }^{95} \mathrm{Nb}$ の放射能測定による放射性降下物の年令推定法}

\author{
帯 刀 正 \\ 信州大学工学部物理学教室 \\ 長野市若里500
}

高分解能を有する $\gamma$ 線用 $\mathrm{Ge}(\mathrm{Li})$ 検出器を用いて, 放射性降下物の年令を推定する一方法につ いて述へている。この方法による放射性降下物の年令はつぎのよ5にして算出される。すなわち試 料としては1967年12月 24 日に行なわれた中国核爆発実験による強放射能粒子を用い，それにふくま 
れる ${ }^{95} \mathrm{Nb}$ の放射能をある一定時間，隔てて 2 回測定し，得られた実測值から求めている。その結 果は実際の年令值とかなりよく一致しており，また ${ }^{95} \mathrm{Zr}$ と ${ }^{95} \mathrm{Nb}$ の放射能比によって得られた推 定值とるよく一致している。推定結果に対して予期される誤差および放射性降下物の年令を 1 日〜 2 日の誤差範囲内で推定するのに必要な ${ }^{95} \mathrm{Nb}$ の原子数と測定時間間隔の精度が表に示される。 